DIE FUNKTIONEN DER WERBUNG IM SYSTEM DER ZENTRALEN WIRTSCHAFTSLENKUNG. By Endre Antal. Osteuropastudien der Hochschulen des Landes Hessen, series 1. Giessener Abhandlungen zur Agrarund Wirtschaftsforschung des europäischen Ostens, vol. 52. Wiesbaden: Otto Harrassowitz, 1970. 170 pp. DM 24, paper.

Although socialism has not yet developed a counterpart of Madison Avenue, socialist advertising has recently been on the rise. Compared with the capitalist West, and possibly even with pre-1939 Eastern Europe, these are still modest, but not negligible, efforts. The total advertising expenditures of the COMECON economies are estimated at about one billion U.S. dollars, which amounts to from 0.01 to 0.05 percent of the national incomes of these countries (p. 52). Most of this amount is spent on export promotion and thus represents a desperate COMECON trade offensive in Western markets. However, domestic advertising is also becoming more widespread, hence costly. In sharp contrast to the past, the managers of East European socialism have begun paying homage to activities that were once identified with "parasitic capitalism."

Antal is a methodical writer. His is a carefully organized monograph on the new phenomenon of socialist advertising. Starting with definitions and a brief historical survey in chapters 1 and 2, he proceeds to a systematic analysis of his subject. In chapter 3 the macroeconomic and social functions of advertising under socialist planning are compared with those in the private market economy. An extensive comparison of the microeconomic (betriebswirtschaftliche) functions follows in chapter 4. To an economist much of this discussion-which constitutes the bulk of the volume-is of intrinsic interest, albeit some well-traveled ground is covered and there is a proliferation of "principles" and taxonomies that reminds one of the more pedestrian business textbooks.

Perhaps most noteworthy is the author's assessment of socialist advertisers. Their arsenal-mainly a variety of printed matter-is deemed badly antiquated. Reportedly not even in the highly competitive West can the socialist exporters resort to expensive radio and television campaigns. Often, because of inexperience and bureaucratic bungling, there is ineffectiveness and waste; Antal, especially in his informative footnotes, provides many striking examples. Among the "specific features of advertising in Eastern Europe" (pp. $154 \mathrm{ff}$.), Antal stresses the lack of adaptability (Anpassungsfähigkeit) caused by incredibly long printing cyclestwo years for a calendar, one year for a catalogue, and so forth. Furthermore, advertising is said to be indiscriminately scattered among hundreds of insignificant items. These and other failings of East European advertisers are bluntly ascribed to "many years of neglect of advertising under the system of Soviet-type central planning" (p. 158). Nevertheless, according to the author, there were some notable successes (the Polish "vodka, geese, and ham campaign" in West Germany; Czechoslovakia's pavilion at the Montreal Expo). Thus, he concludes, the prospects for effective advertising under the new economic systems of Eastern Europe "are propitious" (p. 160).

In a sense Antal's book is another contribution to the growing literature on convergence. The writer correctly emphasizes the relation of his special topic to the larger problem of market-oriented reforms in Eastern Europe. On the uncertain premise that socialist advertisers will some day "catch up" with their Western colleagues, one is left with the uneasy afterthought that toothpaste and deodorant commercials may indeed be the price of a freer and more efficient 
economy. And if they are, the price would certainly not be too high to pay for the East European peoples.

ANDRZeJ BRZESKI

University of California, Davis

DIVORCE IN POLAND: A CONTRIBUTION TO THE SOCIOLOGY OF LAW. By Jan Górecki. Studies in the Social Sciences, 5. The Hague and Paris: Mouton, 1970. 156 pp. Paper.

This is an empirical study of the divorce law in Poland, which bases the determination of reasons for divorce upon the formula received from Soviet law. Between the wars Polish jurists included a new family law-dealing with both marriage and divorce-in their program of legislative reform. The draft was prepared, but for a number of reasons (rooted primarily in local traditions) enactment was delayed. It was adopted in 1945 after the liberation of Poland. The 1945 law was replaced in 1950 by the law modeled after the 1944 Soviet Family, which featured a simple formula permitting either spouse to sue for divorce in case of a "complete and lasting disintegration of marital relations." The 1950 law was eventually replaced by newer codes, but the divorce formula remained unchanged, and the present divorce practice of Polish courts represents twenty years of continued tradition.

The main purpose of the inquiry was to establish the actual meaning of the key words that determine the reason for divorce-through questionnaires, direct observation of divorce proceedings in court, and interviews with lawyers, judges, and litigants. The data gathered by this method were supplemented by more traditional sources, such as the statistics printed by the Ministry of Justice, data available in other studies, and so forth.

Although the empirical part of the book is largely based on a somewhat limited number of answers to questionnaires, the conclusions arrived at are interesting, and it deserves the attention of jurists and sociologists.

KAzIMIERz GrzYBowsKI

Duke University Law School

\section{INFORMATION AND REFLECTION: ON SOME PROBLEMS OF CYBER- NETICS AND HOW CONTEMPORARY DIALECTICAL MATERIAL- ISM COPES WITH THEM. By Peter Paul Kirschenmann. Dordrecht: D. Reidel. New York: Humanities Press, 1970. xv, 225 pp. \$14.00.}

Peter Kirschenmann's book focuses on some of the philosophical problems that have arisen in the Soviet Union as Marxist-Leninist philosophers have tried to adapt cybernetics to dialectical materialism. Kirschenmann deals especially with attempts to show that despite its very general methods, which give it the appearance of a philosophy, cybernetics is merely a science that deals with a number of systems and processes, but within a limited framework which does not place it in competition with dialectical materialism. The author's particular concern is a subdivision of cybernetics-information theory-which he defines as dealing with "signal processes and their relations in communications devices." This choice of topic is especially relevant because of the close connection between information theory and the basic Marxist-Leninist philosophical assumption regarding the material nature of ultimate reality. The book serves as a case study of the limitations 